Trinity University

Digital Commons@ Trinity

English Faculty Research

English Department

$10-1997$

\title{
Wittgenstein's Ladder: Poetic Language and the Strangeness of the Ordinary
}

Michael Fischer

TrinityUniversity, mfischer@trinity.edu

Follow this and additional works at: https://digitalcommons.trinity.edu/eng_faculty

Part of the English Language and Literature Commons

\section{Repository Citation}

Fischer, M. (1997). Wittgenstein's ladder: Poetic language and the strangeness of the ordinary [Review of the book Wittgenstein's ladder: Poetic language and the strangeness of the ordinary by M. Perloff]. Philosophy and Literature, 21(2), 489-491. doi: 10.1353/ phl.1997.0035

This Book Review is brought to you for free and open access by the English Department at Digital Commons @ Trinity. It has been accepted for inclusion in English Faculty Research by an authorized administrator of Digital Commons @ Trinity. For more information, please contact jcostanz@trinity.edu. 
revenge, according to Goodhart, is not a simple plot device as much as a commentary on the danger of triggering any plot. Hamlet's reluctance to avenge his father's death is an attempt to live in a plotless world because Shakespeare understands that plots (revenge, Oedipal, or other) have been drawing blood since time began. The story of Joseph names the refusal to sacrifice innocent blood, Goodhart insists, so that the very uttering of the name "Joseph" is a reminder to the Jews of the persistence of the sacrificial principle in human history. Finally, Goodhart attempts to read in Auschwitz the prophetic wisdom that there is no such thing as a common humanity that might save us from our own violence. The Holocaust explodes the myth that humanism might provide the means to stop the spilling of human blood; it kills humanism that humans might take responsibility for killing each other. In each case, then, Goodhart takes on a work whose history of interpretation is formidable and long and gives us an individual expression of what he has been taught by it.

The greatness of a work of criticism—or at least its ambition-may be judged by the greatness of the works of literature with which it converses. This is, of course, an embattled idea today. Whether or not one believes in great books, however, one must still admit that the burden of history and its unceasing anxiety of influence lie with greater weight on works of literature that have been read for a long time. To say that Goodhart has succeeded in making his individual experience of these great works into an experience valuable to others is the highest compliment.

UNIVERSITY OF MichigAN

TOBin SiEbers

Wittgenstein's Ladder: Poetic Language and the Strangeness of the Ordinary, by Marjorie Perloff; xvii \& 285 pp. Chicago: University of Chicago Press, 1996, $\$ 27.95$.

In a frequently quoted remark from Philosophical Investigations. Wittgenstein comments on our overlooking things because they are familiar, or right in front of us every day: "One is unable to notice something-because it is always before one's eyes" (\$129). We take these things for granted instead of appreciating their strangeness. For readers of this journal, one of these familiar things might be the very project of drawing on philosophy while discussing works of literature. Not every critic does this; the New Critics, for instance, hardly ever did. From a certain point of view, turning to philosophy feels forced or odd, in need of explanation and defense.

In Marjorie Perloff's Wittgenstein's Ladder: Poetic Language and the Strangeness of 
the Ordinary, the works of literature under discussion include texts by Gertrude Stein, Samuel Beckett, Thomas Bernhard, Ingeborg Bachmann, Lyn Hejinian, and other poets and novelists. The philosopher Perloff calls on to help elucidate these texts is Wittgenstein. She compounds the possible oddity of using Wittgenstein by admitting not only that several of these writers never read him but that he probably would not have liked their work. Nevertheless, she refers to the "Wittgensteinian poetics" of Robert Creeley and Hejinian and the "Wittgensteinian fictions" of Bernhard and Bachmann. Although I agree that there is something "Wittgensteinian" about these writers, I think that the connection goes even deeper than Perloff assumes.

Perloff begins to establish some common ground between Wittgenstein and these writers by characterizing Wittgenstein as a kind of artist himself. In Culture and Value Wittgenstein remarks that "philosophy ought really to be written only as a form of poetry." With this comment in mind, Perloff is less interested in tracking the argument of his work than in following what Stanley Cavell has called Wittgenstein's "spiritual struggle." Perloff's opening chapters demonstrate how that struggle informs Wittgenstein's writing from the Tractatus through the Investigations. She traces Wittgenstein's endless self-revision, showing how his writing is "'aesthetic' in its imaginative deployment of exempla, apposite images, parataxes, and sudden leaps of faith" (p. 15). Like some modernist avant-garde texts, Wittgenstein's writings resist being paraphrased; they foreground and question their own construction; and they gravitate toward provisional, fragmentary forms-most famously, the philosophical remarks and sketches that make up the Investigations.

Seeing Wittgenstein as a modernist artist is a useful, if perhaps familiar, way of characterizing him. I am less convinced by the biographical details that Perloff lets into the discussion once she likens Wittgenstein's writings to literary texts. It is as if in her view seeing Wittgenstein as an artist humanizes him and encourages us to see in his writings the imprint of his personal life. Wittgenstein's war experience, for example, transforms "the Tractatus from logical, scicntific treatise to something quite different" (p. 25). "The imperious tone of the Investigations" betrays "Wittgenstein the upper-class, singularly wealthy, culturally superior Viennese male" (p. 76). Wittgenstein's Jewishness as well as his nationality distances him from English culture and makes him "determined to live inside the ordinary language field of his adopted nation, and yet to be so aware of its vagaries" (p. 76). Finally, Wittgenstein's homosexuality and his consequent need to disguise his own feelings bring about his anxious insistence, or hope, that no one else can know another person's feelings with certainty (p. 77).

I agree that the circumstances of Wittgenstein's life align him with other modernist outsiders. But for me the more powerful ties between Wittgenstein and the poets and novelists that Perloff goes on to examine surface in the texts that they write, not in the lives that they lead. Perloff's tying Wittgenstein's work to his gender, class, ethnicity, and sexual orientation feels mechanical to me. I 
don't say that such biographical and historical factors are irrelevant, only that Perloff fails to shed any new light on how they enter into Wittgenstein's work.

Perloff is on firmer ground when, after describing the aesthetic form of Wittgenstein's work, she turns to the writers who resemble him. She is an astute reader of difficult literary works such as Stein's Marry Nettie, Beckett's Watt, Creeley's Away, and Hejinian's The Cold of Poetry. The sophistication that I sometimes miss in her reading of Wittgenstein is always apparent in her reading of these literary texts, as when she notes that although Stein's Marry Nettie can "be construed as an antipatriarchal, antiauthoritarian, nonlinear, and oblique lesbian fiction," in Stein's case such "specific gender construction is never the whole story" ( $p .111$ ). The question raised by Perloff's readings is what these readings gain by invoking Wittgenstein. Sometimes ideas in Wittgenstein provide Perloff a context for understanding a writer: his discussion of identity in the Investigations, for example, helps her to explain Stein's experiments with language. Sometimes Perloff translates literary plots into Wittgensteinian categories, observing, for instance, that "in Wittgensteinian terms, Watt begins as an Augustinian" (p. 139). Occasionally she finds "a peculiar symbiosis" (p. 135) between Wittgenstein and a writer, sometimes direct influence (in Bachmann). In general, stylistic and formal parallels, a common vocabulary, and shared concerns (principally with ordinary language) establish an underlying affinity between Wittgenstein and these writers, leading Perloff to see him as their "natural ally" (p. 182) and "patron saint" (p. 3).

In my view, these writers are "Wittgensteinian" in the ways that Perloff mentions and she deserves credit for pointing out their often surprising kinship with his work. I wish, however, that she would have probed more deeply into the resemblances that she has uncovered. Part of the problem here stems from her willingness to set aside the argument of Wittgenstein's work (leaving it to philosophers) and to focus instead on its literary qualities. As a result of this caution, we get disappointing and quick characterizations of Wittgenstein's thought, as when Perloff repeatedly refers to his "commonsense" approach to ordinary language, forms of life, and other key topics. I miss a full sense of what drives Wittgenstein's writing, what he is struggling with-why, in fact, appealing to common sense is not his way of handling philosophical problems. Lacking such a grasp of the underlying issues motivating Wittgenstein's writing, Perloff makes his similarity to a writer such as Stein seem like an interesting coincidence or superficial parallel-worth noting, to be sure, but not productive of new insight into the intellectual work done by this kind of writing. In short, Perloff's emphasis on the literary dimensions of Wittgenstein's texts and the Wittgensteinian aspects of various poems and novels is helpful, so far as it goes. But by going more deeply into what is at stake in his writing, she could have done an even better job of illuminating the literary texts that carry on his legacy. 